DOI

\title{
ОСОБЛИВОСТІ ВИКЛАДАННЯ ДИСЦИПЛІНИ “ГІГІЄНА ТА ЕКОЛОГІЯ” ДЛЯ ІНОЗЕМНИХ СТУДЕНТІВ МЕДИЧНИХ УНІВЕРСИТЕТІВ
}

\author{
I. А. Мищенко \\ ДВНЗ “Івано-Франківський національний медичний університет”

\section{PECULIARITIES OF TEACHING OF “HYGIENE AND ECOLOGY” FOR FOREIGN STUDENTS OF MEDICAL UNIVERSITIES}

\author{
I. A. Myshchenko
}

\author{
SHEI “Ivano-Frankivsk National Medical University”
}

\begin{abstract}
Стаття присвячена актуальним питанням, пов’язаним з викладанням курсу “Гігієна та екологія” іноземним студентам з англійською мовою навчання в процесі професійної підготовки на медичних факультетах. Розглянуті педагогічні прийоми для підвищення мотивації до вивчення дисципліни, поліпшення засвоєння матеріалу, висвітлена актуальність набуття практичних навичок роботи з приладами для оцінки параметрів навколишнього середовища. Наведені конкретні методичні прийоми, що використовуються в педагогічному процесі.
\end{abstract}

The article is devoted to actual questions of teaching of "Hygiene and Ecology" for foreign English speaking students of medical universities during professional training at the medical faculties. Studying methods for students' motivation improvement and conceptual learning are considered. Topicality of practical skills during work with special devices for estimation environmental factors is covered. Specific tutorial actions used for teaching process are presented.

Вступ. В умовах реформування системи освіти в Україні та інтеграції держави в європейський освітній простір одним із ключових завдань $є$ залучення іноземних громадян для набуття вищої освіти і надання освітніх послуг на належному рівні. Дослідження свідчать, що українські ВНЗ мають достатній потенціал для боротьби за частку ринку освітніх послуг. За даними МОН України, станом на 2015 рік у 187 ВНЗ України здобувають освіту 65 тисяч студентів зі 146 країн світу. Частка України на міжнародному ринку освіти за чисельністю іноземних студентів становить 1,5 \%. За останні роки кількість іноземних студентів значно збільшилась [1]. Особливої уваги заслуговує медична освіта, адже Україна може нарощувати кількість студентів медичного фаху за рахунок невисоких цін і достатньо якісної академічної школи та досить високого рівня знань у передових ВНЗ. Згідно з дослідженнями, галузь “Охорона здоров’я” є найбільш пріоритетною для іноземних студентів, її частка складає 31 \% [2].

(C) I. А. Мищенко
Івано-Франківський національний медичний університет (ІФНМУ) входить до топ-10 ВНЗ України за кількістю іноземних студентів на денній формі навчання і займає п’яте місце серед українських ВН3 [2]. Разом з тим, для залучення іноземних громадян в українські ВНЗ медичного профілю треба приділяти першочергову увагу якості освітніх послуг та особливостям особистості іноземних студентів, що пов’язані з культурними та мовними відмінностями, етапами соціальної, психологічної та фізіологічної адаптації до нових умов.

Основна частина. Основний матеріал дисципліни “Гігієна та екологія” для студентів спеціальності “Лікувальна справа” викладається на третьому курсі навчання протягом V та VI навчальних семестрів після завершення опанування базових дисциплін 3 біології, хімії, фізіології, необхідних для успішного засвоєння гігієнічних знань. Основним завданням викладача, на етапі початкового опанування будь якої дисципліни, є формування свідомої особистої мотивації студента до її вивчення. Оскільки “Гігієна та екологія” не відноситься до дисциплін клінічного циклу, проблема підвищення 
мотивації студентів до вивчення цієї дисципліни може бути вирішена за допомогою декількох педагогічних прийомів. По-перше, це руйнування стереотипу, який панує серед деяких іноземних студентів, про те, що гігієна не вивчається в закордонних ВНЗ і є пережитком радянських часів. Розкриваючи основну мету гігієни та розповідаючи про галузі гігієнічних досліджень, студентам треба пояснювати, що у розвинених країнах проблемі профілактики надається важливе значення, що підтверджується в тому числі сумами витрат на дослідження факторів ризиків здоров'я людини, розробку програм моніторингу здоров’я населення, освітніх та консультаційних програм тощо [3, 4]. Лідером у цьому напрямку залишаються США, в яких витрати на охорону здоров’я перевищують 7000 \$ на людину на рік (за даними 2006 року) [5]. Педагогічний досвід працівників кафедри свідчить і про зацікавленість іноземних студентів інформацією про існування курсів, кафедр, ВНЗ та науково-дослідних інститутів за кордоном, які спеціалізуються на викладанні та вивченні гігієнічних проблем. Як приклади можна навести чисельні курси та кафедри “Public Health”, або суспільного здоров’я, в країнах ЄС, США, Канади або досягнення таких університетів, як "London School of Hygiene and Tropical Medicine" (Лондонський університет гігієни та тропічної медицини) чи роботу національних агентств щодо стандартів харчових продуктів “Food Standards Agency” тощо.

Другим моментом підвищення мотивації студентів до вивчення дисципліни, на наш погляд, $є$ розуміння їі прикладного характеру. Цілком очевидно, що підручники та навчальні посібники для іноземних студентів не можуть сформувати практичні навички. Тому особливу увагу на практичних заняттях слід приділяти роботі з сучасними приладами для оцінки, наприклад, рівнів та біологічної дії фізичних факторів середовища. Адже, як свідчить педагогічний досвід колег, фокус оцінювання в медичній освіті поступово зміщується з простої перевірки запам'ятовування медичних наукових фактів до оцінки дій студента. Таким чином відбувається зміщення оцінювання 3 першого (“маю уявлення, знаю”) та другого (“знаю, як саме”) рівнів до третього (“демонструю”), а інколи навіть четвертого (“роблю сам”) [6]. Практичні навички роботи з приладами не тільки поліпшують запам'ятовування матеріалу, але й формують розуміння взаємозв’язку в ланцюгу “фактор - ри- зик здоров'я”. Особливо корисними, на наш погляд, є практичні заняття, проведені в умовах виробництва. Так, наприклад, на кафедрі гігієни та екології ІФНМУ практикувалося проведення одного $з$ практичних занять з гігієни праці на швейній фабриці. Студенти розподілялися на підгрупи, кожна з яких виконувала вимірювання параметрів фізичних факторів конкретного цеху. На наступному занятті складався загальний протокол обстеження з підведенням підсумку та обгрунтуванням рекомендацій. Доцільно було б доповнити таке заняття також дослідженням фізіологічних реакцій організму, наприклад показників серцево-судинної системи та деяких інших, специфічних для дії досліджуваних факторів, систем. Для майбутніх лікарів це $\epsilon$ необхідною передумовою розуміння важливості фізіологічних зсувів до появи клінічних проявів патології, спричинених виробничим процесом. У цілому, якомога частіше звернення студентів до раніше засвоєного матеріалу 3 різних дисциплін, а саме фізики і хіміі, як основи принципів вимірювання рівнів та концентрацій виробничих та природних факторів, фізіології та психофізіології як маркерів первинних реакцій з боку організму, допомагає більш глибокому розумінню міждисциплінарних зв’язків. 3 іншого боку, це актуалізує роль природничо-наукових дисциплін у майбутній професії. У медичній освіті такий підхід не тільки формує комплекс активно функціонуючих алгоритмів, але й дозволяє ефективно оцінити клінічну компетентність студентів.

На жаль, проведення таких комплексних практичних занять ускладнюється через недостатнє матеріально-технічне забезпечення державних ВНЗ, а саме через недостатню кількість, а в деяких випадках відсутність сучасних приладів та обладнання. Часткове вирішення цього питання, на нашу думку, полягає у налагодженні співпраці з профільними науково-дослідними інститутами, санітарно-епідеміологічними станціями, залученні іноземних грантових проектів. Втім, такий перехід має відбуватися поступово за підтримки ВНЗ з боку держави.

Під час викладання дисципліни “Гігієна та екологія” доцільно використовувати різноманітні методи навчання, які стимулюють мотивацію студентів, поліпшують рівень засвоєння матеріалу тощо. Використання таких методів детермінується формою заняття та видом роботи. Так, наприклад, під час лекційних та практичних занять, а також виконання індивідуальних завдань та самостійної роботи 
ефективними методами навчання $є$ різноманітні інформаційно-комунікаційні технології; робота у малих групах може активно використовуватися під час проведення практичних занять та виконання індивідуальних завдань; проблемне навчання підвищує рівень сприйняття матеріалу під час проведення лекцій.

Важливим моментом під час викладання іноземним студентам $€$ рівень володіння англійською мовою як викладачами, так і студентами. Викладачі мають постійно підвищувати рівень знання розмовної, письмової англійської мови, а також сприйняття мови на слух та навички роботи з текстами. Це сприяє підвищенню ефективності викладання матеріалу, об'єктивності оцінювання усних студентських відповідей, перевірки правильності складання протоколів тощо. Для багатьох студентів англійська мова не $є$ рідною, неналежний рівень володіння якою часто призводить до значних труднощів у сприйнятті матеріалу і впливає на успішність. Тому вимоги до належного рівня володіння англійською мовою мають ставитися як до викладачів, що працюють з іноземними студентами, так і до абітурієнтів з інших країн. Досвід роботи кафедри з іноземцями, які мають труднощі з володінням англійською мовою, свідчить про ефек-

\section{Список літератури}

1. Лозовий В. С. Україна на міжнародному ринку освітніх послуг вищої освіти : аналітична записка / B. С. Лозовий. - Доступно : http://www.niss.gov.ua/ articles/1695/.

2. Актуальні статистично-аналітичні показники надання освітніх послуг іноземцям. - Доступно : http:// intered.com.ua/.

3. Expenditure on prevention activities under SHA 2011: Supplementary Guidance. June 2013. - Доступно : http:// www.oecd.org/els/.

4. The Power of prevention: Chronic disease...the public health challenge of the $21^{\text {st }}$ century. National center for chronic diseases prevention and health promotion. 2009. 18 pp. - Доступно : http://www.cdc.gov/chronicdisease/ pdf/2009-Power-of-Prevention.pdf. тивність індивідуальних завдань 3 поточних тем практичного заняття. Тобто такі студенти мають не тільки прочитати відповідний розділ у підручнику, але й занотувати основні моменти у вигляді план-конспекту, або структурно-логічної схеми. В психолого-педагогічній літературі зазначається, що близько 80 \% інформації людина сприймає через органи зору, близько 15 \% - через слух і 5 \% - через дотик, нюх і смак. Проте, коли йдеться не тільки про сприйняття, але і про запам' ятовування інформації, то чільне місце належить моторній, тобто руховій пам’яті. Тому особа, яка навчається, запам'ятає матеріал набагато краще, коли побачить, почує і доторкнеться, тобто сама щось відтворить - запише формули та означення, намалює ескізи та схеми, а вже потім застосує на практиці одержані знання [7, 8].

Висновок. Навчання студента являє собою творчий процес. Для поліпшення якості навчання іноземних громадян викладач має насамперед посилити мотивацію так, щоб виникла потреба набуття нових знань, робити акцент на набутті практичних навичок та розумінні міждисциплінарних зв'язків, урізноманітнити навчальний процес відповідними методами навчання та організувати пізнавальний процес відповідно до індивідуальних особливостей англомовних студентів та рівнів володіння мовою.

5. National health expenditures aggregate, per capita amounts, percent distribution, and average annual percent growth, by sours of funds: selected calendar years 1960-2007 [Internet]. Baltimore, MD: Centers for Medicare and Medicaid Services; 2008. Available from: http://www.cms.hhs. gov.National-HealthExpendData/downloads/tabels/pdf.

6. Господарський I. Особливості навчання іноземних студентів в субординатурі медичного вузу / I. Господарський. - Доступно : http://www.experts.in.ua/baza/ analitic/index.php?ELEMENT_ID=10950.

7. Алексюк А. М. Педагогіка вищої освіти в Україні / А. М. Алексюк. - К. : Либідь, 1999. - 557 с.

8. Никандров Н. Д. Организационные формы и методы обучения в высшей школе / Н. Д. Никандров // В кн.: Проблемы педагогики в высшей школе. - Ленинград, 1992. - 190 с. 